\title{
Chroniberia: The Ongoing Development of a Geochronological GIS Database of Iberia
}

\author{
C. Lopes, A. Ferreira, M. Chichorro, M. F. Pereira, J. A. Almeida \\ and A. R Solá
}

\begin{abstract}
Geochronological comparisons of large datasets are facilitated by the use of structured databases. This paper reports the ongoing development of CHRONIBERIA, a geochronological GIS database that will provide access to zircon $\mathrm{U}-\mathrm{Pb}$ age datasets from Iberia. The database will also integrate relevant distinct datasets from other correlative regions around the world to construct a framework based on stratigraphic, sedimentological, and palaeogeographical data.
\end{abstract}

Keywords Geochronology · Zircon U-Th-Pb • Database • GIS · Iberia

A detailed and precise temporal framework is essential for exploring the richness of the geological record (Bowring and Schmitz 2003). Zircon U-Th-Pb geochronology has been widely used to provide an exact measure of time (Davis et al. 2003), which has give rise to large geochronological datasets. Geochronological comparisons of such large datasets are facilitated by the use of structured databases. Several distinct geochronological databases and database systems have been developed in the last decade, including: CHRONOBANK, a GIS-based geochronological database (Brazil, Silva et al. 2003); NGDB, the National Geochronological Database (USA, Silva et al. 2003); and OZCHRON (Australia, Sircombe 2006). DateView (a freeware desktop database system; Eglington 2004), the StratDB/IGCP509 initiative (a database system and web interface with links to the geochronology database DateView; Eglington et al. 2009), and the EarthChem initiative (http://www.earthchem.org/earthchemWeb/index.jsp) are all part of the

C. Lopes · A. Ferreira $\cdot$ M. Chichorro $(\varangle) \cdot$ J. A. Almeida

CICEGe, Departamento de Ciências da Terra, Faculdade de Ciências e Tecnologia,

Universidade Nova de Lisboa, 2829-516 Caparica, Portugal

e-mail: ma.chichorro@fct.unl.pt

M. F. Pereira

IDL, Departamento de Geociências, ECT, Universidade de Évora, Évora, Portugal

A. R Solá

Unidade de Geologia, Hidrogeologia e Geologia Costeira, LNEG, Lisbon, Portugal

R. Rocha et al. (eds.), STRATI 2013, Springer Geology,

DOI: 10.1007/978-3-319-04364-7_138, @ Springer International Publishing Switzerland 2014 
most recent developments to construct an international database system. These databases use GIS tools to improve spatial analysis, to generate maps, and to integrate distinct data set (Silva et al. 2003; Eglington 2004). To understand the geological history of the Gondwana supercontinent and related peripheral magmatic arcs (the Avalonia and Cadomian terranes), a geochronological GIS database of Iberia (CHRONIBERIA), based on the zircon contents of rocks from Iberia, has been created.

\section{Design of the Geochronological Database}

In the conception of the database, the following main issues were considered: the nature of the data; the types of queries expected; and the workflow and main goals of the GONDWANA project (a research project that focuses on obtaining new U$\mathrm{Pb}$ zircon ages in southwestern Iberia and which intends to analyse them together with data already published on Iberia). Some technical considerations were also addressed: the number of users and usage pattern; the type of database (relational); the usage of the database (for editing/read-only); the degree of demand (high/low); the type of software; the connection/transaction to the web; and the administration of the database.

Based on a set of typical queries normally applied to isotope data (see Eglington 2004), the nature, detail, and amount of information to be used in the CHRONIBERIA were, on a first level, defined as follows: Which samples are associated with some specified age? Which samples from a specific formation are associated with some specified age? What is the age of a specified geological unit or of an event? How do dates from one area or geological entity compare with those from other areas? What is the geographical distribution of dates in some area relative to their geological interpretation? How do initial ratios vary with time in some areas? It is clear that spatial information is required in addition to chronological.

Based on a synthetic workflow related to isotope data acquisition, the major entities and relations of the database were defined (Fig. 1). The schematic design of the database was subsequently defined based on a diagram of entities and relationships.

Some technical considerations were then addressed, regarding the type of software. Databases using Microsoft Access offer, for example, better and more user-friendly manipulation of alphanumerical data and easier generation of data forms and queries involving several tables, whereas ArcGIS databases (geodatabases) provide the possibility of making spatial queries of and spatial operations on the data. Original datafile formats for ArcGIS geodatabases can be stored and managed in Microsoft Access data files, which offers a hybrid solution as a starting point. 


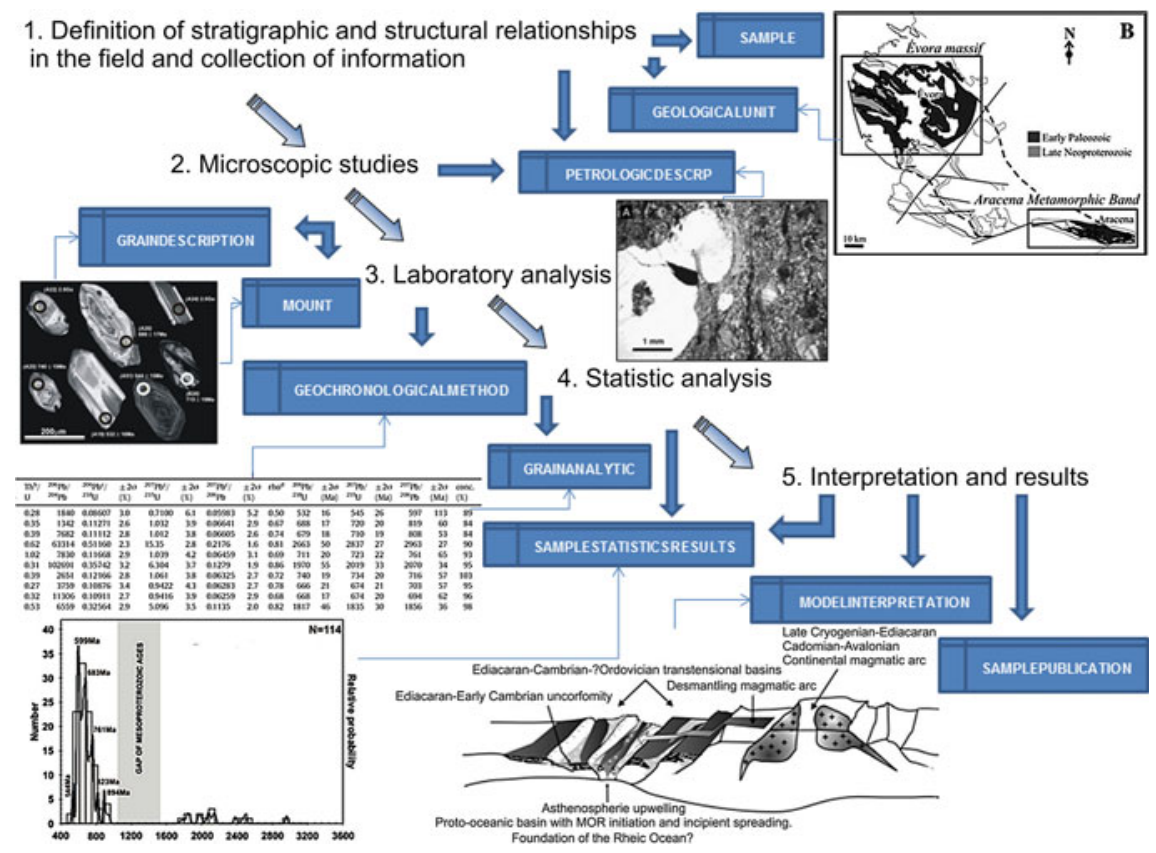

Fig. 1 Synthetic workflow and correspondence with the main tables of the database. Some data images are shown from Solá et al. (2008); Chichorro et al. (2008); and Pereira et al. (2012) illustrating the type of data stored in each table

\section{Implementation of the Database and Data Loading}

The database was first implemented in Microsoft Access. The information is stored in 18 tables, interlinked by key-data columns, and centralized in the sample table where the geographical information is stored. In several tables, multiple values were stored to form a list of predefined values to improve the precision and speed of the feeding process (data loading). In the present phase, the database has been loaded with data acquired from the GONDWANA project. Not all these data are yet completely loaded in the database; in some cases, there are still data and information missing, such as some geographical coordinates, auxiliary information, and even analytical data.

\section{Follow-up}

In the follow-up, more data from the project and from the literature will be added to the database. The geodatabase, already implemented in ArcGIS, will be 
developed and tested. Moreover, a WebGIS (Geographic Information System for the World Wide Web) will be implemented.

Acknowledgments C. Lopes acknowledges a research grant of 12 months duration that was sponsored by project GONDWANA-PTDC/CTE-GIX/110426/2009 funded by Fundação para a Ciência e Tecnologia (Portugal). It is a contribution to project PEst-OE/CTE/UI4073/2014.

\section{References}

Bowring, S. A., \& Schmitz, M. D. (2003). High-precision U-Pb zircon geochronology and the stratigraphic record. Reviews in Mineralogy and Geochemistry, 53, 305-326.

Chichorro, M., Pereira, M. F., Díaz-Azpiroz, M., Williams, I. S., Fernández, C., Pin, C., et al. (2008). Cambrian ensialic rift-related magmatism in the Ossa-Morena Zone (Évora-Aracena metamorphic belt, SW Iberian Massif): $\mathrm{Sm}-\mathrm{Nd}$ isotopes and SHRIMP zircon U-Th- $\mathrm{Pb}$ geochronology. Tectonophysics, 461, 91-113.

Davis, D., Williams, I. S., \& Krogh, T. E. (2003). Historical development of zircon geochronology. Reviews in Mineralogy and Geochemistry, 53, 145-182.

Eglington, B. M. (2004). DateView: a windows geochronology database. Computers \& Geosciences, 30, 847-858.

Eglington, B. M., Reddy, S. M., \& Evans, D. A. D. (2009). The IGCP 509 database system; design and application of a tool to capture and illustrate litho- and chrono-stratigraphic information for Palaeoproterozoic tectonic domains, large igneous provinces and ore deposits; with examples from Southern Africa (in Palaeoproterozoic supercontinents and global evolution). Geological Society Special Publications, 323, 27-47.

Pereira, M. F., Solá, A. R., Chichorro, M., Lopes, L., Gerde, A., \& Silva, J. B. (2012). NorthGondwana assembly, break up and paleogeography: $\mathrm{U}-\mathrm{Pb}$ isotope evidence from detrital and igneous zircons of Ediacaran and Cambrian rocks of SW Iberia. Gondwana Research 22(3-4), 866-881. http://dx.doi.org/10.1016/j.gr.2012.02.010

Silva, L. C., Rodrigues, J. B., Silveira, L. M. C., \& Pimentel, M. M. (2003). The Brazilian National Geochronological Database: Chronobank, IV South American Symposium on Isotope Geology, Salvador.

Sircombe, K. N. (2006). Standardising geochronological data. Geochimica et Cosmochimica Acta, 70, A594.

Solá, A. R., Pereira, M. F., Williams, I. S., Ribeiro, M. L., Neiva, A. M. R., Montero, P., et al. (2008). New insights from U-Pb zircon dating of Early Ordovician magmatism on the northern Gondwana margin: The Urra Formation (SW Iberian Massif, Portugal). Tectonophysics, 461, 114-129. 